\title{
Stem cell therapy for diabetic foot ulcers: a review of preclinical and clinical research
}

\author{
Lara Lopes ${ }^{1,2}$, Ocean Setia', Afsha Aurshina', Shirley Liu', Haidi Hu', Toshihiko Isaji ${ }^{1}$, Haiyang Liu', Tun Wang ${ }^{1}$, \\ Shun Ono' ${ }^{1}$ Xiangjiang Guo ${ }^{1}$, Bogdan Yatsula', Jianming Guo ${ }^{3}$, Yongquan Gu ${ }^{3}$, Tulio Navarro ${ }^{2}$ and Alan Dardik ${ }^{1,4^{*}}$
}

\begin{abstract}
Background: Diabetic foot ulcer (DFU) is a severe complication of diabetes, preceding most diabetes-related amputations. DFUs require over US\$9 billion for yearly treatment and are now a global public health issue. DFU occurs in the setting of ischemia, infection, neuropathy, and metabolic disorders that result in poor wound healing and poor treatment options. Recently, stem cell therapy has emerged as a new interventional strategy to treat DFU and appears to be safe and effective in both preclinical and clinical trials. However, variability in the stem cell type and origin, route and protocol for administration, and concomitant use of angioplasty confound easy interpretation and generalization of the results.
\end{abstract}

Methods: The PubMed, Google Scholar, and EMBASE databases were searched and 89 preclinical and clinical studies were selected for analysis.

Results: There was divergence between preclinical and clinical studies regarding stem cell type, origin, and delivery techniques. There was heterogeneous preclinical and clinical study design and few randomized clinical trials. Granulocyte-colony stimulating factor was employed in some studies but with differing protocols. Concomitant performance of angioplasty with stem cell therapy showed increased efficiency compared to either therapy alone.

Conclusions: Stem cell therapy is an effective treatment for diabetic foot ulcers and is currently used as an alternative to amputation for some patients without other options for revascularization. Concordance between preclinical and clinical studies may help design future randomized clinical trials.

Keywords: Stem cell therapy, Cell therapy, Diabetic foot ulcer, Diabetic wound, Critical limb ischemia, Wound healing, Amputation

\section{Background}

The prevalence of diabetes mellitus has increased precipitously due to worldwide changes in nutrition and lifestyle, and is currently estimated to affect 425 million adults in 2017 and to increase to 629 million patients by 2045 [1]. Diabetic foot ulcer (DFU), a major complication of diabetes, is defined by The International Working Group on the Diabetic Foot as a full-thickness wound located below the ankle in a diabetic patient, and is associated with diabetic neuropathy and peripheral arterial disease [2]. More than $2 \%$ of the diabetic population develops a new foot ulcer each year leading to US $\$ 9.1$ billion

\footnotetext{
* Correspondence: alan.dardik@yale.edu

${ }^{1}$ Vascular Biology and Therapeutics Program and Department of Surgery,

Yale School of Medicine, Yale University, New Haven, CT, USA

${ }^{4}$ VA Connecticut Healthcare System, West Haven, CT, USA

Full list of author information is available at the end of the article
}

spent on care per year in the USA alone [3, 4]. In addition to pain, infection, amputation, and impaired mobility, DFUs are also associated with severe economic, social, and psychological sequelae. One amputation occurs every $30 \mathrm{~s}$ as a consequence of diabetic complications, and $84 \%$ of these amputations are preceded by a DFU $[5,6]$.

Current treatment guidelines for DFU recommend debridement, management of infection, revascularization, and off-loading pressure to promote healing [7]. However, ischemia, infection, neuropathy, and metabolic disorders frequently delay wound healing, a critical challenge for both patients and clinicians [8]. Recent advances in understanding the cellular and molecular complexities of wound healing have identified coagulation, inflammation, cell migration, and proliferation as critical steps required for tissue remodeling and healing [9]. Stem cell-based therapy

(C) The Author(s). 2018 Open Access This article is distributed under the terms of the Creative Commons Attribution 4.0 International License (http://creativecommons.org/licenses/by/4.0/), which permits unrestricted use, distribution, and 
has emerged as a promising therapeutic strategy to treat DFU. Stem cells synthesize and secrete cytokines that promote cell recruitment, immunomodulation, extracellular matrix remodeling, angiogenesis, and neuroregeneration, all of which promote wound healing [10-12]. Stem cells are also capable of differentiating into various cell types, such as myofibroblasts, keratinocytes, pericytes, and endothelial cells that may participate in wound healing [13].

Although initial reports of stem cell therapy have shown efficacy, the different parameters used within each of these studies prevents easy interpretation and generalization of these reports, and therefore recommendations for treatment of DFU with stem cell therapy are difficult to standardize [14]. This study reviews current literature reporting stem cell therapy for DFU, with specific attention to the type and origin of the stem cells used for treatment, routes of cell administration, use of granulocyte-colony stimulating factor (G-CSF), and adjunctive use and comparison to percutaneous transluminal angioplasty.

\section{Methods}

The PubMed, EMBASE, and Google Scholar databases were searched on November 1, 2017. The search was performed using MeSH terms for "diabetic foot" paired with MeSH terms for "stem cell(s)" or "progenitor cells", which resulted in 256 articles available for screening (Fig. 1).
Abstracts for all these articles were screened, and review and experimental research articles describing stem cell therapy for diabetic foot ulcers were included. Articles were excluded if they were duplicated articles, nontherapeutic studies, nondiabetic wound trials, studies not employing stem cells, studies that used unspecified cell populations, and non-English articles with incomplete English abstracts.

Screening the initial 256 articles led to selection of 58 studies, consisting of 45 primary research studies and 13 reviews, which were reviewed in depth. A secondary screening was performed on the 1351 references obtained from the 13 reviews, yielding an additional 54 primary research studies, for a total of 99 primary research studies. Full-text review of these studies excluded an additional 10 articles, leading to the final inclusion of 89 primary research articles.

Each of the 89 research papers were examined in detail to determine study design (preclinical or clinical), stem cell type, stem cell origin, route of administration, use of G-CSF mobilization, and adjunctive use of percutaneous transluminal angioplasty.

\section{Results}

\section{Study design}

Of the 89 selected articles, there were 54 preclinical studies (60.7\%) [15-68] and 36 clinical studies (40.4\%)

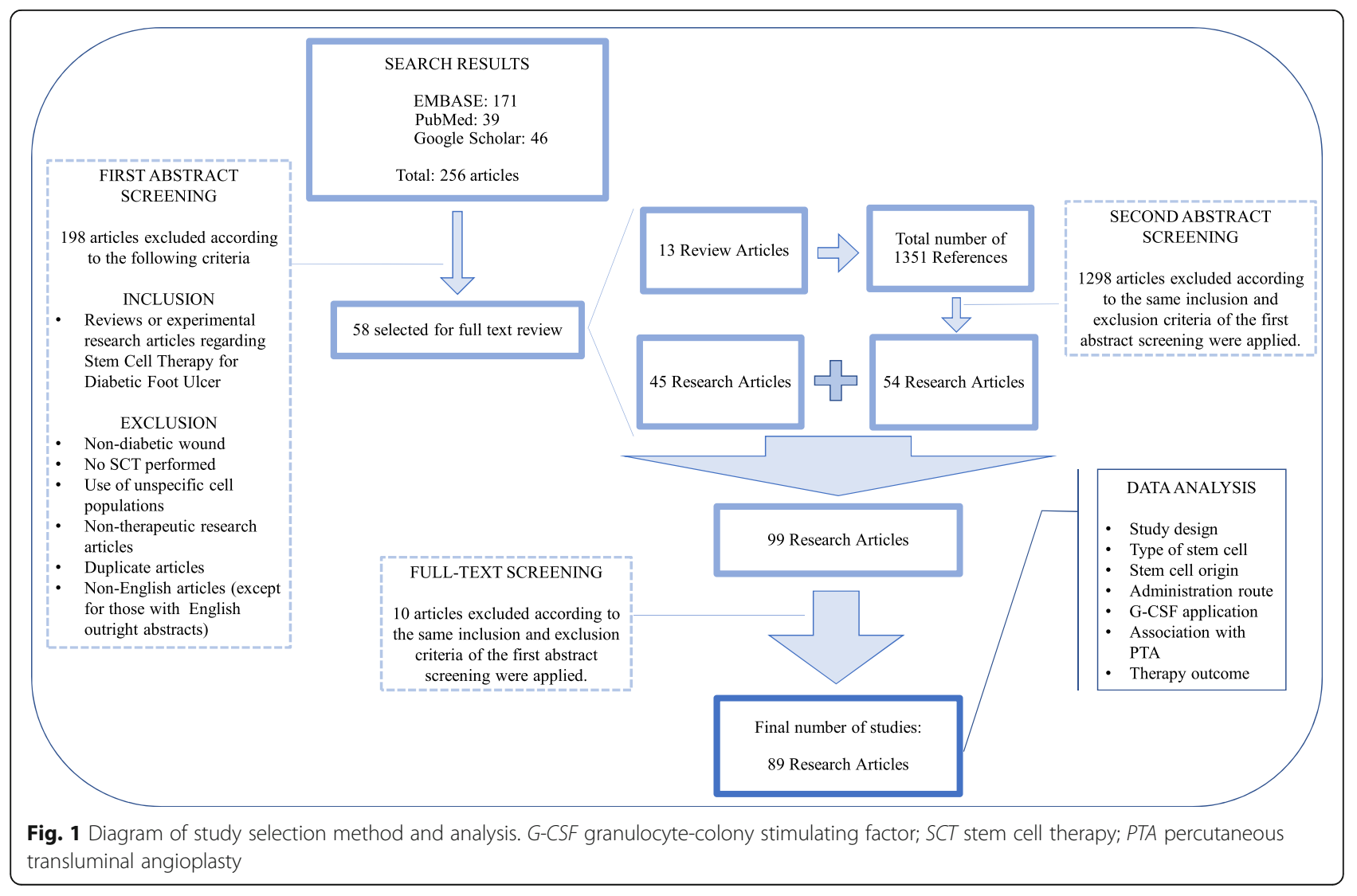


[38, 69-103]; one article reported data for both preclinical and clinical studies [38].

\section{Clinical studies}

One clinical study was retrospective [75] and 35 studies were prospective. Six studies were case reports [38, 85, 92-95] and 18 were case series $[38,69,74,77,78,80,82-84$, 86-90, 96, 99, 100, 102, 103]. Three were cohort studies [70, 76, 101], one was a case-control study [75], and eight were randomized clinical trials [71-73, 79, 81, 91, 97, 98]. The results for the eight randomized clinical trials selected among these studies are summarized in Table 1.

\section{Preclinical studies}

The murine DFU model (31 articles) was most frequently used for preclinical research, with streptozotocin injections (30 articles) being the most common method to induce diabetes. Some of the most frequently observed parameters were a single wound model (22 articles), back wound location (30 articles), and wound diameter 5-6 $\mathrm{mm}$ (18 articles).

\section{Stem cell type}

\section{Adult stem cells}

A total of 53 preclinical studies (98\%) and all of the 36 clinical studies $(100 \%)$ used adult stem cells for treatment (Table 2). Bone marrow-derived mesenchymal stem cells (BM-MSC) were the most frequently used cell type in both preclinical $(n=27 ; 50 \%)$ and clinical $(n=19 ; 53 \%)$ studies. Whereas adipose-derived stem cells (ADSC) were used in 11 preclinical studies (20\%), only three clinical studies (8\%) used this cell type. Human umbilical cord-derived mesenchymal stem cells (hUC-MSC) were used in 12 preclinical (22\%) and four clinical (11\%) studies. Two preclinical articles (4\%) used peripheral blood-derived mesenchymal stem cells (PB-MSC), which was the second most frequent cell type in clinical studies $(n=11 ; 31 \%)$.

Although BM-MSC, PB-MSC, hUC-MSC, and ADSC were the most frequently used stem cell types, other stem cell types were used in some preclinical studies (Table 3). Kim et al. [60] reported enhanced wound healing with use of intradermal injections of human amniotic MSC in a murine DFU model, in comparison to human ADSC or human dermal fibroblasts. Similarly, Zheng et al. [18] related improved ulcer healing in diabetic mice with topical application of micronized amniotic membrane containing human amniotic epithelial cells compared to decellularized membrane. Lv et al. [16] demonstrated that human exfoliated deciduous tooth stem cells have similar healing potential as human BM-MSC in a rat diabetic model. Kong et al. [41] reported wound healing with intradermal injection of human placental MSC in diabetic Goto-Kakizaki rats.
Badillo et al. [58] reported enhanced wound healing after injection of collagen gels containing embryonic fetal liver MSC in diabetic Lep $\mathrm{db} / \mathrm{db}$ mice compared to $\mathrm{CD} 45^{+}$cell treatment. Barcelos et al. [29] used a collagen hydrogel scaffold to deliver human fetal aortic MSC in a murine DFU model.

\section{Embryonic stem cells}

One preclinical study (1.85\%) and none of the clinical studies used embryonic stem cells (ESC; Table 2). Lee et al. [53] used topical mouse ESC in a rat DFU model; despite ESC xenotransplantation in immunocompetent rats, no rejection was observed and the use of pluripotent stem cells did not lead to tumor formation.

\section{Induced pluripotent stem cells}

The use of induced pluripotent stem cells (iPSC) for treatment of DFU has not been reported in any preclinical or clinical studies (Table 2). However, Gerami-Naini et al. [104] showed successful reprogramming of DFU-derived fibroblast cell lines into iPSC and further differentiation into fibroblasts. Okawa et al. [105] showed improvement of neural and vascular function in a polyneuropathy diabetic mouse model following transplantation of neural crest-like cells that were differentiated from murine iPSC. These findings suggest therapeutic potential for iPSC in the treatment of DFU.

\section{Granulocyte-colony stimulating factor}

G-CSF is a cytokine that stimulates bone marrow to mobilize endothelial progenitor cells (EPC), increasing the number of available EPC for healing the DFU; G-CSF is found in wound tissue after acute injury [106]. In steady-state conditions, EPC typically circulate in low concentrations, and thus G-CSF is an important adjunct to promote increased yields of PB-MSC obtained for therapeutic purposes. G-CSF can also directly promote wound healing and reduce the number of surgical interventions in patients with a DFU $[107,108]$. G-CSF was used in 10 clinical studies (Table 4); these studies used different protocols, with a dose range of 150-650 $\mu \mathrm{g}$ and a duration of G-CSF therapy varying from 3 to 6 days, prior to harvesting of BM-MSC and PB-MSC. Xu and Liang [72] found that injections of G-CSF $5 \mu \mathrm{g} / \mathrm{kg} /$ day for 5 days or $10 \mu \mathrm{g} / \mathrm{kg} /$ day for 4 days were the optimal G-SCF administration protocols to mobilize patients with a DFU receiving PB-MSC.

\section{Stem cell origin}

Among the preclinical studies, only four (7\%) examined autologous stem cell delivery; allogeneic stem cells were used in the majority of studies $(n=29 ; 54 \%)$.

Xenotransplantation was performed in 22 preclinical studies $(41 \%)$ and all of them involved application of 
Table 1 Randomized clinical trials reporting stem cell therapy for diabetic foot ulcers

\begin{tabular}{|c|c|c|c|c|c|c|c|}
\hline Author & Year & $N$ & Study design & Type of cell & $\begin{array}{l}\text { Administration } \\
\text { route }\end{array}$ & Results & $\begin{array}{l}\text { Follow-up } \\
\text { (months) }\end{array}$ \\
\hline Debin et al. [91] & 2008 & 50 & $\begin{array}{l}\text { Two groups: } \\
\text { - BM-MSC } \\
\text { - Local wound treatment }\end{array}$ & Autologous BM-MSC & $\begin{array}{l}\text { Intramuscular and } \\
\text { subcutaneous }\end{array}$ & $\begin{array}{l}\text { BM-MSC showed improved: } \\
\text { - Rest pain }(P<0.01) \\
\text { - Claudication distance } \\
\quad(P<0.01) \\
\text { - Ulcer healing }(P=0.012) \\
\text { - Ankle-brachial index } \\
\quad(P<0.01) \\
\text { - Angiogenesis }(P=0.01) \\
\text { - Amputation rate }(0.040)\end{array}$ & 3 \\
\hline Chen et al. [81] & 2009 & 40 & $\begin{array}{l}\text { Two groups: } \\
\text { - BM-MSC } \\
\text { - Conventional individualized } \\
\text { treatment }\end{array}$ & Autologous BM-MSC & Intramuscular & $\begin{array}{l}\text { BM-MSC showed better: } \\
\text { - Blood flow }(P=0.01)\end{array}$ & 3 \\
\hline Dash et al. [97] & 2009 & $6^{* *}$ & $\begin{array}{l}\text { Two groups: } \\
\text { - BM-MSC } \\
\text { - Local wound treatment }\end{array}$ & Autologous BM-MSC & Intramuscular & $\begin{array}{l}\text { BM-MSC showed better: } \\
\text { - Ulcer healing }(P<0.001)\end{array}$ & 3 \\
\hline Lu et al. [79] & 2011 & 41 & $\begin{array}{l}\text { Two groups: } \\
\text { - BM-MSC } \\
\text { - BM-MNC }\end{array}$ & $\begin{array}{l}\text { Autologous BM-MSC } \\
\text { or BM-MNC }\end{array}$ & Intramuscular & $\begin{array}{l}\text { BM-MSC showed better: } \\
\text { - Ulcer healing }(P=0.022) \\
\text { - Limb perfusion }(P=0.040) \\
\text { - Ankle-brachial index } \\
(P=0.017) \\
\text { - } \mathrm{TCPO}_{2}(P=0.001) \\
\text { - Magnetic resonance } \\
\text { angiography analysis } \\
(P=0.018) \\
\text { No difference in pain relief } \\
\text { and amputation rate }\end{array}$ & 6 \\
\hline Jain et al. [98] & 2011 & 48 & $\begin{array}{l}\text { Two groups: } \\
\text { - BM-MSC } \\
\text { - Peripheral blood }\end{array}$ & Autologous BM-MSC & Injection* and spray & $\begin{array}{l}\text { BM-MSC showed better ulcer } \\
\text { healing }(P<0.05)\end{array}$ & 3 \\
\hline Kirana et al. [73] & 2012 & 24 & $\begin{array}{l}\text { Two groups: } \\
\text { - BM-MSC } \\
\text { - Tissue repair cells (TRC) }\end{array}$ & Autologous BM-MSC & $\begin{array}{l}\text { Injection* and } \\
\text { intraarterial }\end{array}$ & $\begin{array}{l}\text { - BM-MSC } 83 \% \text { ulcer healing } \\
\text { vs TRC } 80 \% \text { ulcer healing } \\
\text { - BM-MSC and TRC had } \\
\text { better TCPO }(P=0.092) \\
\text { - BMC-MSC improved } \\
\text { ankle-brachial index } \\
(P<0.10) \\
\text { - Angiogenesis detected in } \\
\text { seven of the BM-MSC/ } \\
\text { TRC groups }\end{array}$ & 12 \\
\hline Xu et al. [72] & 2016 & 127 & $\begin{array}{l}\text { Eight groups: } \\
\text { - Group A (G-CSF BID } \\
5 \mu \mathrm{\mu g} / \mathrm{kg} / \mathrm{day}) ; \text { four } \\
\text { subgroups: } 4,5,6 \text { or } 7 \text { days } \\
\text { - Group B (G-CSF BID } \\
10 \mu \mathrm{\mu g} / \mathrm{kg} / \mathrm{day}) ; \text { four } \\
\text { subgroups: } 4,5,6 \text { or } \\
7 \text { days }\end{array}$ & Autologous PB-MSC & $\begin{array}{l}\text { Injection* and } \\
\text { topical* }\end{array}$ & $\begin{array}{l}\text { G-CSF BID } 5 \mu \mathrm{g} / \mathrm{kg} / \text { day } \\
\text { during } 5 \text { days is the optimal } \\
\text { dose to mobilize EPC in } \\
\text { DFU patients } \\
\text { All groups reported } \\
\text { improvement of life quality, } \\
\text { pain, cold sensation, clinical } \\
\text { symptoms and ulcer healing }\end{array}$ & $1-15$ \\
\hline Qin et al. [71] & 2016 & 53 & $\begin{array}{l}\text { Two groups: } \\
\text { - Angioplasty } \\
\text { - Angioplasty and stem cell } \\
\text { therapy }\end{array}$ & Allogeneic hUC-MSC & $\begin{array}{l}\text { Intraarterial and } \\
\text { intramuscular }\end{array}$ & $\begin{array}{l}\text { Combination group showed } \\
\text { better: } \\
\text { - Ankle-brachial index } \\
(P<0.05) \\
\text { - Skin temperature }(P<0.05) \\
\text { - Claudication distance } \\
(P<0.05) \\
\text { - } \mathrm{TCPO}_{2}(P<0.05)\end{array}$ & $1-3$ \\
\hline
\end{tabular}

"These studies did not specify the subtype of administration route. " In this study, the $\mathrm{n}$ was 24 but only six patients $\mathrm{h}$ ad DFU; 18 patients were diagnosed with Buerger's disease. BID twice a day, BM-MSC bone marrow-derived mesenchymal stem cells, BM-MNC bone-marrow mononuclear cells, DFU diabetic foot ulcer, EPC endothelial progenitor cells, G-CSF granulocyte-colony stimulating factor, hUC-MSC human umbilical cord mesenchymal stem cells, PB-MSC peripheral bloodderived mesenchymal stem cells, $\mathrm{TcPO}_{2}$ transcutaneous oxygen pressure 
Table 2 Stem cell types advantages, disadvantages and use in clinical and preclinical studies

\begin{tabular}{|c|c|c|c|c|c|c|c|}
\hline \multicolumn{2}{|l|}{ Stem cell type } & \multirow{2}{*}{$\begin{array}{l}\text { Advantages } \\
\text { - Donor-specific therapy } \\
\text { - Lower malignancy risk } \\
\text { - Cell-lineage committed } \\
\text { (targeting differentiation) } \\
\text { - No ethical conflict }\end{array}$} & \multirow[b]{2}{*}{$\begin{array}{l}\text { Disadvantages } \\
\text { - Cell lineage committed (limited } \\
\text { differentiation potential) } \\
\text { - Biopsy high surgical risk } \\
\text { - Nondisposable tissue } \\
\text { - Low stem cell concentration } \\
\text { - Cell concentration and } \\
\text { performance influenced by } \\
\text { comorbidities }\end{array}$} & \multicolumn{2}{|c|}{ Clinical studies } & \multicolumn{2}{|c|}{ Preclinical studies } \\
\hline \multirow[t]{4}{*}{ Adult stem cells } & BM-MSC & & & 19 & $(52.8 \%)$ & 27 & $(50.0 \%)$ \\
\hline & PB-MSC & $\begin{array}{l}\text { - Donor-specific therapy } \\
\text { - Lower malignancy risk } \\
\text { - Cell-lineage committed } \\
\text { (targeting differentiation) } \\
\text { - No ethical conflict } \\
\text { - Relatively disposable tissue } \\
\text { - Vein puncture has low surgical } \\
\text { risk } \\
\text { - Simple cell harvesting protocol }\end{array}$ & $\begin{array}{l}\text { - Cell lineage committed (limited } \\
\text { differentiation potential) } \\
\text { - Cell concentration and } \\
\text { performance influenced by } \\
\text { comorbidities } \\
\text { - G-CSF administration needed }\end{array}$ & 11 & (30.5\%) & 2 & $(3.7 \%)$ \\
\hline & hUC-MSC & $\begin{array}{l}\text { - Future donor-specific therapy } \\
\text { - Lower malignancy risk } \\
\text { - Cell-lineage committed } \\
\text { (targeting differentiation) } \\
\text { - Disposable tissue } \\
\text { - UC tissue harvesting has low } \\
\text { surgical risk } \\
\text { - Donor UCB banking storage }\end{array}$ & $\begin{array}{l}\text { - Cell lineage committed } \\
\text { (limited differentiation } \\
\text { potential) } \\
\text { - Immunoincompatibility } \\
\text { - Ethical conflict } \\
\text { - Low stem cell concentration } \\
\text { - Need for UCB banking }\end{array}$ & 4 & (11.1\%) & 12 & $(22.2 \%)$ \\
\hline & ADSC & $\begin{array}{l}\text { - Donor-specific therapy } \\
\text { - Lower malignancy risk } \\
\text { - Cell-lineage committed } \\
\text { (targeting differentiation) } \\
\text { - No ethical conflict } \\
\text { - Disposable tissue } \\
\text { - Liposuction has low surgical risk }\end{array}$ & $\begin{array}{l}\text { - Cell lineage committed (limited } \\
\text { differentiation potential) } \\
\text { - Cell concentration and } \\
\text { performance influenced by } \\
\text { comorbidities }\end{array}$ & 3 & $(8.3 \%)$ & 11 & $(20.4 \%)$ \\
\hline \multicolumn{2}{|c|}{ Embryonic stem cells } & $\begin{array}{l}\text { - High differentiation potential } \\
\text { (pluripotent) }\end{array}$ & $\begin{array}{l}\text { - Increased malignancy risk } \\
\text { - Ethical conflicts }\end{array}$ & 0 & $(0.0 \%)$ & 1 & $(1.9 \%)$ \\
\hline \multicolumn{2}{|c|}{ Induced pluripotent stem cells } & $\begin{array}{l}\text { - High differentiation potential } \\
\text { (pluripotent) } \\
\text { - Somatic-cell memory (targeting } \\
\text { differentiation) } \\
\text { - Donor-specific therapy } \\
\text { - No ethical conflict } \\
\text { - Disposable tissue } \\
\text { - Low cell harvesting } \\
\text { procedure risk }\end{array}$ & $\begin{array}{l}\text { - Increased malignancy risk } \\
\text { - Complex induction protocol } \\
\text { - Somatic-cell memory (biased } \\
\text { differentiation) }\end{array}$ & 0 & $(0.0 \%)$ & 0 & $(0.0 \%)$ \\
\hline
\end{tabular}

ADSC adipose tissue-derived mesenchymal stem cells, $B M-M S C$ bone marrow-derived mesenchymal stem cells, G-CSF granulocyte-colony stimulating factor, hUC-MSC human umbilical cord mesenchymal stem cells, PB-MSC peripheral blood-derived mesenchymal stem cells, UC umbilical cord, UCB umbilical cord blood

human stem cells in animal DFU models. In contrast, $32(89 \%)$ of the clinical studies used autologous stem cells, and only four (11\%) used allogeneic cells. No clinical studies used xenotransplantation to treat a DFU. These studies are summarized in Table 5.

\section{Administration route Local administration}

Nonvascular injections into tissue are currently the most commonly used route of administration to directly treat a DFU; injection was used in 28 preclinical studies (52\%) and 31 clinical studies (86\%) (Table 6). Intradermal $(n=11)$ and subcutaneous $(n=8)$ injections were more frequently used in the preclinical studies while the intramuscular $(n=24)$ route was more commonly used in clinical studies. Kwon et al. [57] reported increased wound strength in a rat DFU model treated with a single local injection of allogeneic BM-MSC; multiple intravenous injections did not significantly increase wound strength $(P=0.06)$, suggesting effectiveness of local injection.

Topical administration was also frequently performed; topical delivery was used in 23 preclinical studies (43\%) and five clinical studies (14\%). Collagen hydrogels and scaffolds were the most commonly used vehicles to deliver cells $[15,17,22,29,34,58,64]$. Various other delivery methods were also used, including a silicon membrane with atelocollagen matrix to deliver murine ADSC [52], and artificial dermis containing human 
Table 3 Studies reporting use of uncommon stem cell types

\begin{tabular}{|c|c|c|c|c|c|c|}
\hline Author & Year & Species & Study design & Type of cell & $\begin{array}{l}\text { Administration } \\
\text { route }\end{array}$ & Results \\
\hline Badillo et al. [58] & 2007 & Mouse & $\begin{array}{l}\text { Three groups: } \\
\text { - MSC } \\
\text { - CD45 } \\
\text { - Control }\end{array}$ & $\begin{array}{l}\text { Allogeneic, murine, } \\
\text { embryonic, fetal liver MSC }\end{array}$ & Intradermal & $\begin{array}{l}\text { MSC group showed smaller } \\
\text { epithelial gap than } C D 45^{+} \\
\text {group }(P<0.004) \\
\text { MSC group showed } \\
\text { increased granulation tissue } \\
\text { area compared to control } \\
\text { group }(P<0.05)\end{array}$ \\
\hline Barcelos et al. [29] & 2009 & Mouse & $\begin{array}{l}\text { Three groups: } \\
\text { - CD } 133^{+} \text {cells } \\
\text { - CD } 133^{-} \text {cells } \\
\text { - Control }\end{array}$ & $\begin{array}{l}\text { Human fetal aorta-derived } \\
\mathrm{CD}_{133^{+}} \text {progenitor cells }\end{array}$ & Collagen hydrogel & $\begin{array}{l}\text { CD133 } 3^{+} \text {group showed } \\
\text { accelerated wound healing } \\
\text { compared to control group } \\
(P<0.05)\end{array}$ \\
\hline Lee et al. [53] & 2011 & Rat & $\begin{array}{l}\text { Four groups: } \\
\text { - Nondiabetic control rats } \\
\text { - Diabetic rats treated with } \\
\text { saline } \\
\text { - Diabetic rats treated with } \\
\text { saline and insulin } \\
\text { - Diabetic rats treated with } \\
\text { ESC and insulin }\end{array}$ & Mouse embryonic stem cells & $\begin{array}{l}\text { Cell suspension } \\
\text { drops }\end{array}$ & $\begin{array}{l}\text { ESC and insulin-treated group } \\
\text { wound healing accelerated } \\
\text { compared to saline and } \\
\text { insulin-treated group } \\
(P<0.05)\end{array}$ \\
\hline Kim et al. [60] & 2012 & Mouse & $\begin{array}{l}\text { Four groups: } \\
\text { - Amniotic MSC } \\
\text { - ADSC } \\
\text { - Human dermal fibroblasts } \\
\text { - Control }\end{array}$ & $\begin{array}{l}\text { Human ADSC and human } \\
\text { amniotic mesenchymal } \\
\text { stem cells }\end{array}$ & Intradermal & $\begin{array}{l}\text { Amniotic MSC group showed } \\
\text { accelerated wound healing } \\
\text { compared with ADSC, dermal } \\
\text { fibroblasts or control groups } \\
(P<0.01)\end{array}$ \\
\hline Kong et al. [41] & 2013 & Rat & $\begin{array}{l}\text { Two groups: } \\
\text { - Human placenta MSC } \\
\text { - Control }\end{array}$ & Human placenta MSC & Intradermal & $\begin{array}{l}\text { Placenta MSC group showed } \\
\text { better wound closure } \\
\text { compared to control group } \\
(P<0.01)\end{array}$ \\
\hline Zheng et al. [18] & 2017 & Mouse & $\begin{array}{l}\text { Three groups: } \\
\text { - Living micronized amniotic } \\
\text { membrane } \\
\text { - Decellularized micronized } \\
\text { amniotic membrane } \\
\text { - Control }\end{array}$ & $\begin{array}{l}\text { Human amniotic epithelial } \\
\text { cells (HAECs) }\end{array}$ & $\begin{array}{l}\text { Micronized amniotic } \\
\text { membrane }\end{array}$ & $\begin{array}{l}\text { Living membrane group had } \\
\text { greater wound healing rate } \\
\text { than decellularized } \\
\text { membrane or control groups } \\
(P<0.001)\end{array}$ \\
\hline Lv et al. [16] & 2017 & Rat & $\begin{array}{l}\text { Three groups: } \\
\text { - Exfoliated deciduous teeth } \\
\text { stem cells } \\
\text { - BM-MSC } \\
\text { - Control }\end{array}$ & $\begin{array}{l}\text { Human BM-MSC and human } \\
\text { exfoliated deciduous teeth } \\
\text { (SHED) }\end{array}$ & Local injection & $\begin{array}{l}\text { SHED group showed } \\
\text { accelerated wound healing } \\
\text { compared to both BM-MSC } \\
\text { and control groups }(P<0.05)\end{array}$ \\
\hline
\end{tabular}

ADSC adipose tissue-derived mesenchymal stem cells, BM-MSC bone marrow-derived mesenchymal stem cells, ESC embryonic stem cells, MSC mesenchymal stem cells

BM-MSC to treat two DFU patients [103]. Artificial dermis was also used for topical application of rat BM-MSC in a rat model [55], and to cover rat autologous ADSC sheets placed on a wound [20]. Micronized amniotic membranes have also been used [18]. Nanofibers containing human BM-MSC [32], human UC-MSC [33], or human ADSC [63] have also been used, as well as fibrin, both in gel to deliver human UC-MSC [54] and as a spray to deliver BM-MSC [38].

In preclinical studies, O'Loughlin et al. [34] and Falanga et al. [38] reported correlation between wound closure and the number of cells topically administered with collagen scaffolds and fibrin spray, respectively. In both studies, there was a significant difference in wound closure when at least $1 \times 10^{6}$ cells were delivered.

\section{Systemic administration}

Endovascular stem cell delivery was performed in five preclinical (9\%) and six clinical (17\%) studies. Intraarterial femoral administration was performed in all six clinical studies while four preclinical studies used the intravenous tail vein route and only one study used the intraarterial femoral route. Zonta et al. [109] reported intraarterial stem cell therapy to be the most effective route for immunomodulatory purposes in rat kidney transplantation when compared to intravenous administration, reducing the incidence of tubulitis, arteritis, and glomerulitis $(p<0.01)$. Ho et al. [110] showed that multiple intravenous MSC doses positively impact glucose homeostasis in murine diabetic model, leading to a gradual decrease in blood sugar after two doses and total remission of diabetes within seven doses. 


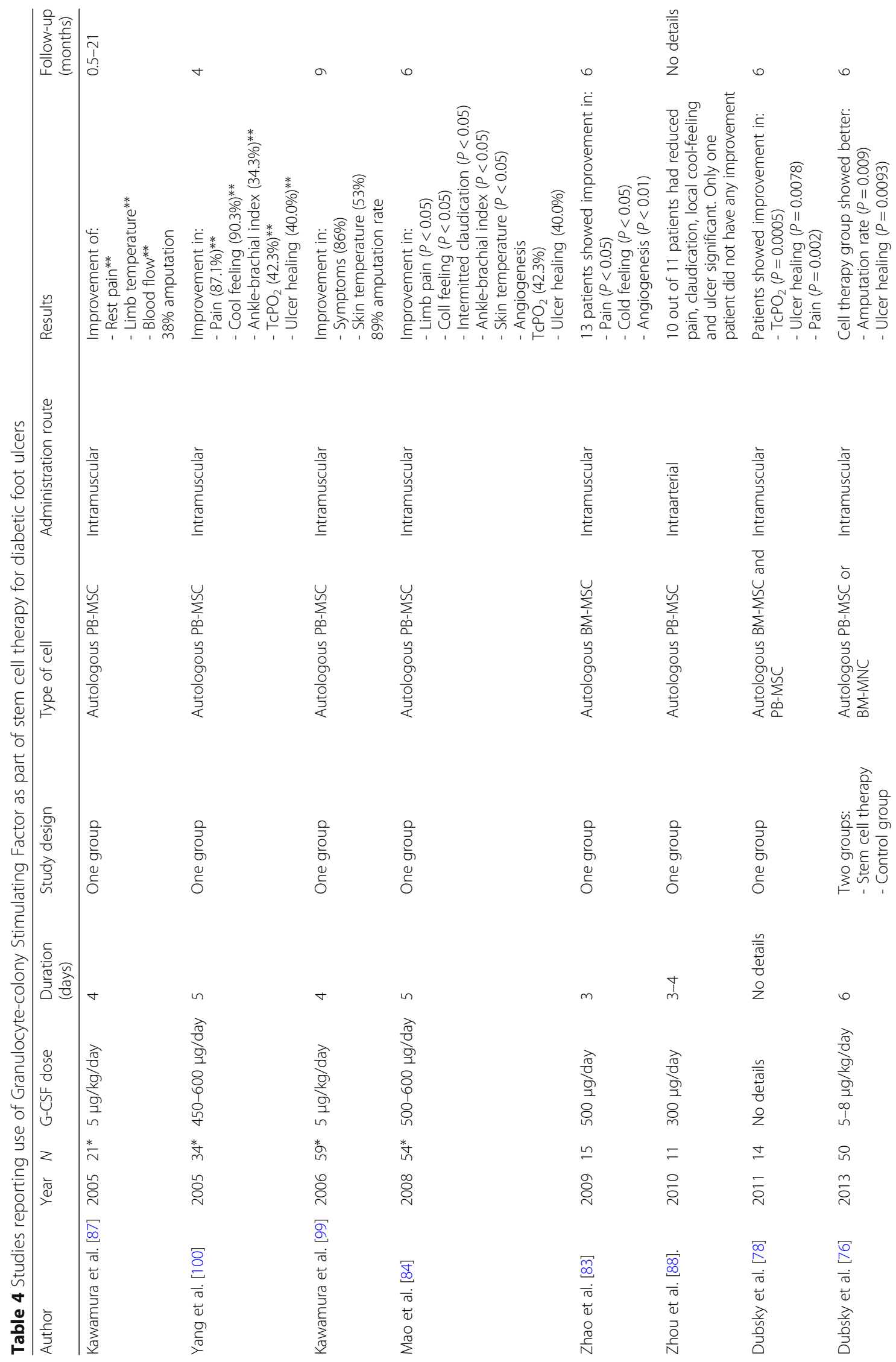




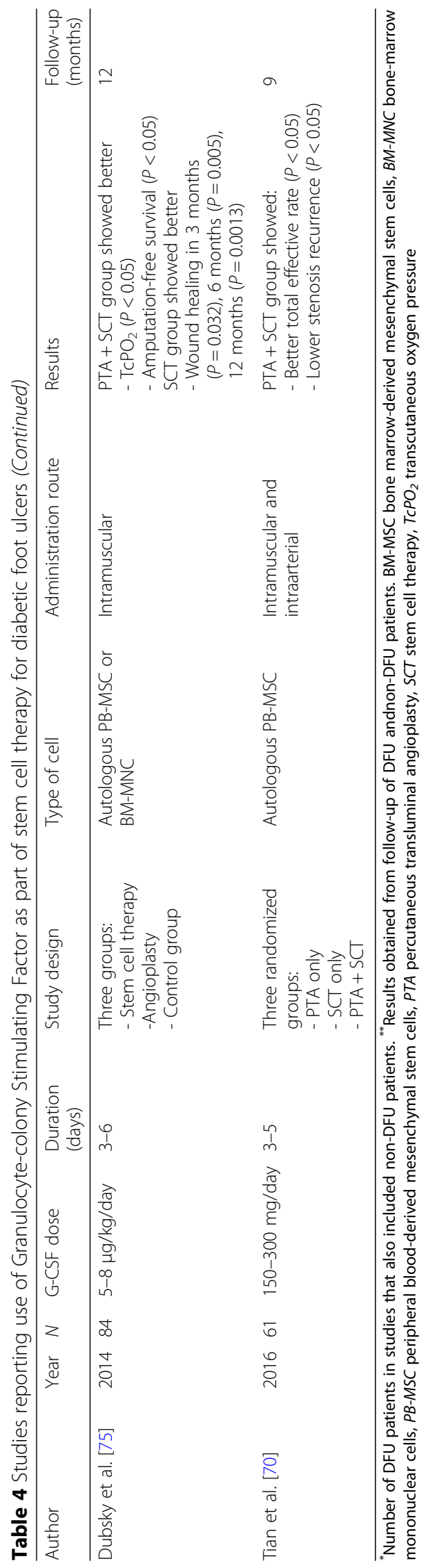


Table 5 Stem cell origin advantages, disadvantages and use in clinical and preclinical studies

\begin{tabular}{|c|c|c|c|c|c|c|}
\hline \multirow{2}{*}{$\frac{\text { Stem cell origin }}{\text { Autologous }}$} & \multirow{2}{*}{$\begin{array}{l}\text { Advantages } \\
\text { - Immunoincompatibility } \\
\text { - No ethical conflict } \\
\text { - No infection transmission risk }\end{array}$} & \multirow{2}{*}{$\begin{array}{l}\text { Disadvantages } \\
\text { - Lower stem cell concentration and } \\
\text { limited healing potential } \\
\text { - Cell harvesting procedural risk }\end{array}$} & \multicolumn{2}{|c|}{ Clinical studies } & \multicolumn{2}{|c|}{ Preclinical studies } \\
\hline & & & 32 & (89\%) & 4 & $(7 \%)$ \\
\hline Allogeneic & $\begin{array}{l}\text { - Healthy stem cell source } \\
\text { - No cell harvesting risk for DFU patient } \\
\text { - Donor banking creation }\end{array}$ & $\begin{array}{l}\text { - Relative immunoincompatibility } \\
\text { - Need for disease screening } \\
\text { - Ethical conflict }\end{array}$ & 4 & $(11 \%)$ & 29 & $(54 \%)$ \\
\hline Xenotransplantation & $\begin{array}{l}\text { - No ethical conflict } \\
\text { - Healthy stem cell source } \\
\text { - No cell harvesting risk for DFU patient } \\
\text { - Donor baking creation }\end{array}$ & $\begin{array}{l}\text { - High immunoincompatibility } \\
\text { - Need for disease screening }\end{array}$ & 0 & $(0 \%)$ & 22 & $(41 \%)$ \\
\hline
\end{tabular}

DFU diabetic foot ulcer

However, as a note of caution, a clinical study of 33 diabetic patients treated with autologous ADSC delivered endovascularly to treat critical limb ischemia reported formation of peripheral microthrombosis in two patients [111]; since diabetic ADSC released higher levels of plasminogen activator and lowered D-dimer formation, it was recommended to follow the D-dimer test prior to delivery of autologous ADSC to diabetic patients.

\section{Stem cell therapy and angioplasty}

Angioplasty is currently an acceptable first-line treatment for selected patients with critical limb ischemia. In patients with critical limb ischemia contributing to the DFU, four clinical studies assessed the efficiency of percutaneous transluminal angioplasty that was performed in adjunctive fashion to the stem cell delivery, and one study compared both treatment options individually (Table 7). Tian [70] reported improved efficacy and reduced restenosis with combination treatment compared to either angioplasty or cell therapy alone. Similarly, intramuscular injection of human UC-MSC combined with angioplasty led to improved ankle-brachial index, claudication distance and transcutaneous oxygen pressure $\left(\mathrm{TcPO}_{2}\right)$ compared to angioplasty alone [71, 101]. In a comparison of angioplasty and cell therapy, cell therapy was associated with superior wound healing despite similar $\mathrm{TcPO}_{2}$ and amputation-free survival [75]. Huang [90] reported enhanced wound healing after angioplasty in addition to intraarterial and intramuscular delivery of autologous PB-MSC.

\section{Discussion}

We report a comprehensive review of 89 preclinical and clinical investigations regarding the use of stem cells to treat DFU. We show that in both preclinical and clinical studies BM-MSC were the main cell type used, in over half the studies (Table 2), and cells were most commonly delivered by local injection (Table 6). As expected, autologous cells were used in the majority of clinical studies (89\%) whereas preclinical studies frequently studied allogeneic and xenogeneic cells (Table 5). Cell number was rarely addressed; G-CSF was used in some studies prior to cell harvest of PB-MSC or BM-MSC, but without standardization of dose or protocol (Table 4). Stem cell therapy performed concomitantly with angioplasty showed more clinical effect compared to either of the therapies performed individually (Table 7).

Among all the studies of stem cell therapy for DFU, only eight of these studies are randomized clinical trials in human patients with DFU (Table 1). However, the heterogeneity among these trials prevents establishing strong conclusions, diminishing the power of any potential recommendations for clinical use of stem cell therapy to treat DFU. Thus, it is logical that future clinical trials should have comparable protocols, doses, cell types, and administration routes to allow good comparison of these expected studies. Unfortunately, the heterogeneity of the clinical trials is predictable from the heterogeneity of the preclinical studies, with differences in most of the parameters including wound models, types of stem cells, wound location, size, and control groups (Table 2).

The "best" stem cell type to treat DFU remains controversial. In both clinical and preclinical studies, predominant use of autologous adult stem cells (Table 2) is justified by simpler isolation protocols, safety, and absence of ethical conflict. While the clinical and preclinical studies commonly reported using bone marrow as the chief source for stem cells, the use of PB-MSC was much more frequent in clinical studies than preclinical studies. However, stem cell therapy with ADSC was far more prevalent in preclinical research, suggesting enthusiasm for using adipose tissue as a potential stem cell source. The fewer number of clinical studies using ADSC could be an artifact of the less convenient isolation process, with need to perform liposuction, as well as reports of an equivalent effectiveness of the stromal vascular fraction to treat DFU $[19,112]$ and also it was the most recent introduced adult stem cell type. Even though there are currently no reports regarding the use of iPSC to treat DFU, this novel cell source combines advantages of both adult and embryonic stem cells; 


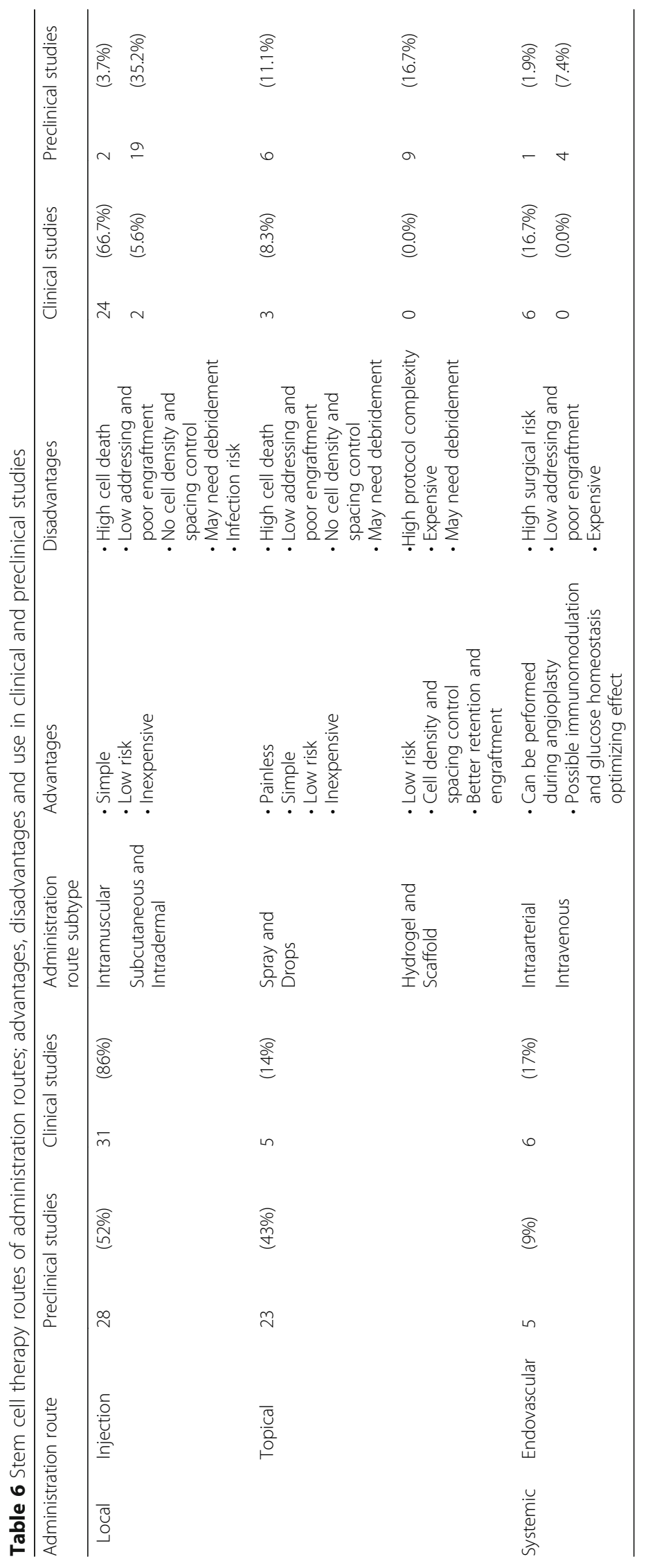




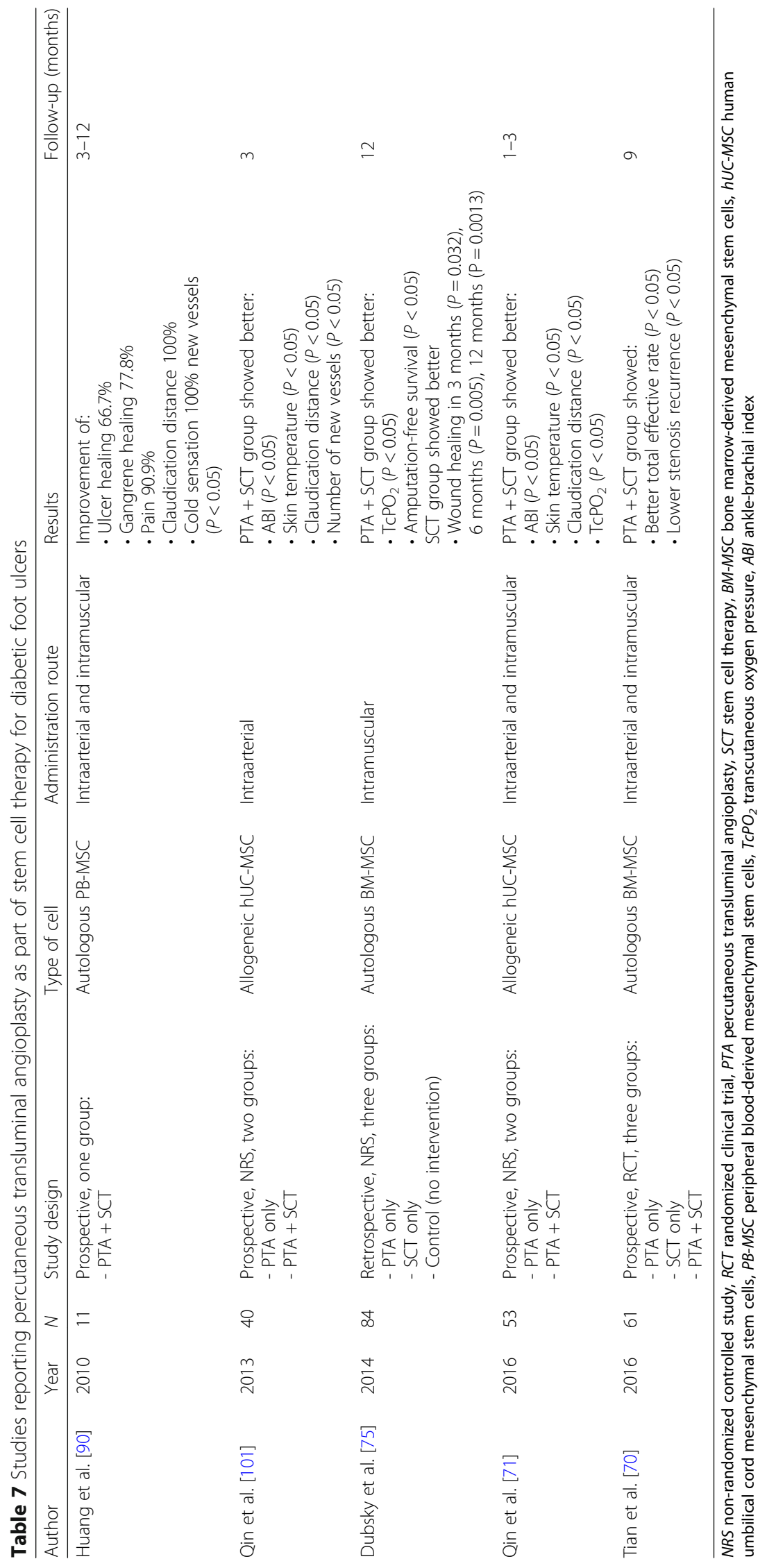


future improvements in somatic cell induction techniques, as well as control of cell differentiation to prevent malignancy, may allow use of iPSC in the future.

Clinical studies mainly reported use of autologous cells, while allogeneic and xenogeneic cells were generally used for preclinical research. Autologous stem cell therapy poses minimal risk of infection, is immunocompatible, and is typically free of ethical or legal issues [113]. However, patients with DFU may have reduced autologous cell function due to the metabolic changes of diabetes as well as advanced age, thereby decreasing stem cell therapy effectiveness and increasing the risk of complications [111, 114-117]. The use of GCSF was observed to be advantageous in wound healing. Even though clinical studies differ regarding EPC mobilization protocol for PB-MSC stem cell therapy, $5 \mu \mathrm{g} / \mathrm{kg}$ injections BID for 5 days were reported as the optimal dose for DFU patients [72].

Alternatively, allogeneic therapy delivers stem cells from younger and healthier donors to the recipient but has the drawback of immunological incompatibility as well as potential legal issues; additionally, strict donor screening is needed to avoid disease transmission [113]. However, if these challenges are met, allogeneic stem cell therapy could be a good source of stem cells, allowing the formation of donation banks as well as potentially the use of cadaveric cells [118]. Immunological incompatibility is the major barrier to using xenogeneic cells. Interestingly, among preclinical studies reporting use of human cells in immunocompetent animal models, wound healing was observed without any immunological adverse effects. These results suggest the potential to use xenogeneic cells in the future.

Current evidence suggests that both local and systemic routes of stem cell therapy delivery are effective to heal DFU. Local injections of the cells were overall the most common method of cell delivery, with the distinction of intramuscular injections mostly being used for clinical studies, while preclinical studies predominantly used intradermal and subcutaneous injections (Table 6). Topical methods were frequently used in preclinical studies (43\%), but less frequently in clinical studies (14\%). Topical delivery within extracellular matrix scaffolds is another variable of interest. The extracellular matrix is a key modulator of cell maintenance, differentiation, proliferation, and self-renewal [119]; hydrogels and collagen scaffolds mimic the native in-vivo environment of stem cells, potentially increasing cell retention and engraftment [120-123] and even cell function [17].

Some commercially available bioengineered products and matrices are available. Graftjacket (Wright Medical Technology, Arlington, TN, USA) is an allogeneic skin graft obtained from donation banks that has demonstrated efficiency in wound treatment [124]. Bovine collagen scaffolds are available (Integra; Life Sciences Corp, Plainsboro, NJ, USA) and have been approved for burns and treatment of DFU [124]. Epifix (MiMedx, Marietta, GA, USA) is a dehydrated anionic membrane containing growth factors that is also a promising vehicle for stem cell therapy [124]. However, large-scale comparative effectiveness studies have not been performed.

\section{Conclusion}

Current evidence points toward stem cell therapy as an effective treatment for human patients with DFU. Clinical and preclinical research studies do not offer a consensus regarding the optimal type of stem cell that should be used, and there is also no established optimal route or protocol to deliver stem cells. Differences within preclinical study designs suggest the need for a consensus regarding an optimal animal model that offers translation to human studies. Although autologous stem cells were the most commonly used stem cell type, it is possible that future studies will explore use of iPSC as well as allogeneic or even xenogenic cells. Administration of G-CSF promotes wound healing and its use is recommended as an adjunct to PB-MSC therapy. Hydrogels and bioscaffolds are promising topical delivery vehicles, but the impact of matrix design and configuration on stem cell function is still unknown. Angioplasty is a promising adjuvant to stem cell therapy in patients needing revascularization, and whether stem cell therapy will be used as an adjuvant to angioplasty remains to be determined.

\section{Abbreviations \\ ABI: Ankle-brachial index; ADSC: Adipose tissue-derived mesenchymal stem cells; BID: Twice a day; BM-MNC: Bone marrow-derived mononuclear cells; BM-MSC: Bone marrow-derived mesenchymal stem cells; DFU: Diabetic foot ulcer; EPC: Endothelial progenitor cells; ESC: Embryonic stem cells; \\ G-CSF: Granulocyte-colony stimulating factor; hUC-MSC: Human umbilical \\ cord mesenchymal stem cells; iPSC: Induced pluripotent stem cells; \\ MSC: Mesenchymal stem cells; NRS: Non-randomized controlled study; PB- \\ MSC: Peripheral blood-derived mesenchymal stem cells; PTA: Percutaneous transluminal angioplasty; RCT: Randomized clinical trial; SCT: Stem cell \\ therapy; $\mathrm{TCPO}_{2}$ : Transcutaneous oxygen pressure; \\ UC-MSC: Umbilical cord-derived mesenchymal stem cells}

\section{Funding}

This work was supported by the National Institutes of Health R01-HL128406 as well as by the resources and the use of facilities at the VA Connecticut Healthcare

System, West Haven, CT, USA.

\section{Availability of data and materials}

The data that support the findings of this study are available from the corresponding author upon reasonable request.

\section{Authors' contributions}

$\mathrm{LL}$ collected, analyzed, and interpreted the data and wrote the manuscript. OS and AA interpreted the data and wrote the manuscript. SL, HH, TI, HL, TW, SO, XG, JG, and BY analyzed the data. YG and TN analyzed and interpreted the data. AD analyzed, interpreted, and wrote the manuscript. All authors read and approved the final manuscript.

Ethics approval and consent to participate Not applicable. 


\section{Consent for publication}

Not applicable.

\section{Competing interests}

The authors declare that they have no competing interests.

\section{Publisher's Note}

Springer Nature remains neutral with regard to jurisdictional claims in published maps and institutional affiliations.

\section{Author details}

'Vascular Biology and Therapeutics Program and Department of Surgery Yale School of Medicine, Yale University, New Haven, CT, USA. ${ }^{2}$ Faculty of Medicine, Federal University of Minas Gerais, Belo Horizonte, Brazil. ${ }^{3}$ Department of Vascular Surgery, Xuanwu Hospital, Capital Medical University, Beijing, China. ${ }^{4}$ VA Connecticut Healthcare System, West Haven, CT, USA.

Received: 11 May 2018 Revised: 15 June 2018

Accepted: 20 June 2018 Published online: 11 July 2018

\section{References}

1. International Diabetes Federation. IDF Diabetes Atlas, 8th edn. Brussels: International Diabetes Federation, 2017. http://www.diabetesatlas.org.

2. Apelqvist J, Bakker K, van Houtum WH, Nabuurs-Franssen MH, Schaper NC. International consensus and practical guidelines on the management and the prevention of the diabetic foot. International Working Group on the Diabetic Foot. Diabetes Metab Res Rev. 2000;16(Suppl 1):S84-92.

3. Rice JB, Desai U, Cummings AK, Birnbaum HG, Skornicki M, Parsons NB. Burden of diabetic foot ulcers for medicare and private insurers. Diabetes Care. 2014;37:651-8.

4. Abbott CA, Carrington AL, Ashe H, Bath S, Every LC, Griffiths J, Hann AW, Hussein $\mathrm{A}$, Jackson $\mathrm{N}$, Johnson $\mathrm{KE}$, Ryder $\mathrm{CH}$, Torkington R, Van Ross ER, Whalley AM, Widdows P, Williamson S, Boulton AJ. The North-West Diabetes foot care study: incidence of, and risk factors for, new diabetic foot ulceration in a community-based patient cohort. Diabet Med. 2002;19:377-84.

5. Moxey PW, Gogalniceanu P, Hinchliffe RJ, Loftus IM, Jones KJ, Thompson MM, Holt PJ. Lower extremity amputations-a review of global variability in incidence. Diabet Med. 2011;28:1144-53.

6. Reiber GE. Lower extremity foot ulcers and amputations in diabetes. In: Diabetes in America. Washington DC, US: US Government Printing Office; 1995;p. 409-28.

7. Alexiadou K, Doupis J. Management of diabetic foot ulcers. Diabetes Ther. 2012;3:4.

8. Baltzis D, Eleftheriadou I, Veves A. Pathogenesis and treatment of impaired wound healing in diabetes mellitus: new insights. Adv Ther. 2014:31:817-36

9. Demidova-Rice TN, Hamblin MR, Herman IM. Acute and impaired wound healing: pathophysiology and current methods for drug delivery, part 1: normal and chronic wounds: biology, causes, and approaches to care. Adv Skin Wound Care. 2012;25:304-14.

10. Isakson M, de Blacam C, Whelan D, McArdle A, Clover AJP. Mesenchymal stem cells and cutaneous wound healing: current evidence and future potential. Stem Cells Int. 2015;2015:831095.

11. Cao Y, Gang X, Sun C, Wang G. Mesenchymal stem cells improve healing of diabetic foot ulcer. J Diabetes Res. 2017;2017:9328347.

12. Mizukami H, Yagihashi S. Exploring a new therapy for diabetic polyneuropathy - the application of stem cell transplantation. Front Endocrinol (Lausanne). 2014;5:45.

13. Sasaki M, Abe R, Fujita $Y$, Ando S, Inokuma D, Shimizu H. Mesenchymal stem cells are recruited into wounded skin and contribute to wound repair by transdifferentiation into multiple skin cell type. J Immunol. 2008;180:2581-7.

14. Guo J, Dardik A, Fang K, Huang R, Gu Y. Meta-analysis on the treatment of diabetic foot ulcers with autologous stem cells. Stem Cell Res Ther. 2017:8:228.

15. da Silva LP, Santos TC, Rodrigues DB, Pirraco RP, Cerqueira MT, Reis RL, Correlo VM, Marques AP. Stem cell-containing hyaluronic acid-based spongy hydrogels for integrated diabetic wound healing. J Investig Dermatol. 2017;137:1541-51.
16. LV Y, Ge L, Zhao Y. Effect and mechanism of SHED on ulcer wound healing in Sprague-Dawley rat models with diabetic ulcer. Am J Transl Res. 2017:9:489-98.

17. Assi R, Foster TR, He H, Stamati K, Bai H, Huang Y, Hyder F, Rothman D, Shu C, HomerVanniasinkam S, Cheema U, Dardik A. Delivery of mesenchymal stem cells in biomimetic engineered scaffolds promotes healing of diabetic ulcers. Regen Med. 2016;11:245-60.

18. Zheng $Y$, Ji S, Wu H, Tian S, Zhang Y, Wang L, Fang H, Luo P, Wang X, Hu X, Xiao S, Xia Z. Topical administration of cryopreserved living micronized amnion accelerates wound healing in diabetic mice by modulating local microenvironment. Biomaterials. 2017;113:56-67.

19. Shi R, Jin Y, Cao C, Han S, Shao X, Meng L, Cheng J, Zhang M, Zheng J, Xu J, Li M. Localization of human adipose-derived stem cells and their effect in repair of diabetic foot ulcers in rats. Stem Cell Res Ther. 2016;7:155.

20. Kato Y, Iwata T, Morikawa S, Yamato M, Okano T, Uchigata Y. Allogeneic transplantation of an adipose-derived stem cell sheet combined with artificial skin accelerates wound healing in a rat wound model of type 2 diabetes and obesity. Diabetes. 2015;64:2723-34.

21. Kato J, Kamiya H, Himeno T, Shibata T, Kondo M, Okawa T, Fujiya A, Fukami A, Uenishi E, Seino Y, Tsunekawa S, Hamada Y, Naruse K, Oiso Y, Nakamura J. Mesenchymal stem cells ameliorate impaired wound healing through enhancing keratinocyte functions in diabetic foot ulcerations on the plantar skin of rats. J Diabetes Complicat. 2014;28:588-95.

22. Hou C, Shen L, Huang Q, Mi J, Wu Y, Yang M, Zeng W, Li L, Chen W, Zhu C. The effect of heme oxygenase-1 complexed with collagen on MSC performance in the treatment of diabetic ischemic ulcer. Biomaterials. 2013;34:112-20.

23. Wan J, Cai Q, Liu Y. Effect of different transplantations with bone-marrow derived mesenchymal stem cells on diabetic foot ulcers in rats. Zhong Nan Da Xue Xue Bao Yi Xue Ban. 2013;38:347-55.

24. Zhao Q-S, Xia N, Zhao N, Li M, Bi C-L, Zhu Q, Qiao G-F, Cheng Z-F. Localization of human mesenchymal stem cells from umbilical cord blood and their role in repair of diabetic foot ulcers in rats. Int J Biol Sci. 2014;10:80-9.

25. Wan J, Cai Q, Liu Y. Effect of different transplantations with bonemarrow derived mesenchymal stem cells on diabetic foot ulcers in rats. Zhong Nan Da Xue Xue Bao Yi Xue Ban. 2013 38(4):347-55.

26. Zhou N, Wang QP, Jin XF, Hou ZL, Peng BK, Dan QQ, Wang TH. Effect of human umbilici mesenchymal stromal cells implantation on the BDNF expression in diabetic foot rats. Sichuan Da Xue Xue Bao Yi Xue Ban. 2013:44:931-4

27. Wan J, Cai Q, Liu Y. Effect of intramuscular bone marrow-derived mesenchymal stem cell transplantation in the leg for treatment of diabetic foot ulcers in rats. Nan Fang Yi Ke Da Xue Xue Bao. 2012;32:1730-6.

28. Elsharawy MA, Naim M, Greish S. Human CD34+ stem cells promote healing of diabetic foot ulcers in rats. Interact Cardiovasc Thorac Surg. 2012;14:288-93.

29. Barcelos LS, Duplaa C, Krankel N, Graiani G, Invernici G, Katare R, Siragusa M, Meloni M, Campesi I, Monica M, Simm A, Campagnolo P, Mangialardi G, Stevanato L, Alessandri G, Emanueli C, Madeddu P. Human CD133+ progenitor cells promote the healing of diabetic ischemic ulcers by paracrine stimulation of angiogenesis and activation of Wnt signaling. Circ Res. 2009;104:1095-102.

30. Cai Q. Allogeneic bone marrow mesenchymal stem cells for the treatment of diabetic foot ulcers in rats and vascular endothelial growth factor expression. J Clin Rehabil Tissue Eng Res. 2010;14:6733-7.

31. Cil N, Oguz EO, Mete E, Cetinkaya A, Mete GA. Effects of umbilical cord blood stem cells on healing factors for diabetic foot injuries. Biotech Histochem. 2017:92:15-28.

32. Lu H, Wu X, Wang Z, Li L, Chen W, Yang M, Huo D, Zeng W, Zhu C. Erythropoietin-activated mesenchymal stem cells promote healing ulcers by improving microenvironment. J Surg Res. 2016;205:464-73.

33. He S, Shen L, Wu Y, Li L, Chen W, Hou C, Yang M, Zeng W, Zhu C. Effect of brain-derived neurotrophic factor on mesenchymal stem cell-seeded electrospinning biomaterial for treating ischemic diabetic ulcers via milieu-dependent differentiation mechanism. Tissue Eng Part A. 2015;21:928-38.

34. O'Loughlin A, Kulkarni M, Creane M, Vaughan EE, Mooney E, Shaw G, Murphy M, Dockery P, Pandit A, O'Brien T. Topical administration of allogeneic mesenchymal stromal cells seeded in a collagen scaffold augments wound healing and increases angiogenesis in the diabetic rabbit ulcer. Diabetes. 2013;62:2588-94.

35. Javazon EH, Keswani SG, Badillo AT, Crombleholme TM, Zoltick PW, Radu AP Kozin ED, Beggs K, Malik AA, Flake AW. Enhanced epithelial gap closure and 
increased angiogenesis in wounds of diabetic mice treated with adult murine bone marrow stromal progenitor cells. Wound Repair Regen. 2007;15:350-9.

36. Wu Y, Chen L, Scott PG, Tredget EE. Mesenchymal stem cells enhance wound healing through differentiation and angiogenesis. Stem Cells. 2007;25:2648-59.

37. Wan J, Xia L, Liang W, Liu Y, Cai Q. Transplantation of bone marrow-derived mesenchymal stem cells promotes delayed wound healing in diabetic rats. J Diabetes Res. 2013;2013:647107.

38. Falanga V, Iwamoto S, Chartier M, Yufit T, Butmarc J, Kouttab N, Shrayer D, Carson P. Autologous bone marrow-derived cultured mesenchymal stem cells delivered in a fibrin spray accelerate healing in murine and human cutaneous wounds. Tissue Eng. 2007;13:12991312.

39. Kuo YR, Wang CT, Cheng JT, Wang FS, Chiang YC, Wang CJ. Bone marrowderived mesenchymal stem cells enhanced diabetic wound healing through recruitment of tissue regeneration in a rat model of streptozotocininduced diabetes. Plast Reconstr Surg. 2011;128:872-80.

40. Castilla DM, Liu Z-J, Tian R, Li Y, Livingstone AS, Velazquez OC. A novel autologous cell based therapy to promote diabetic wound healing. Ann Surg. 2012;256:560-72.

41. Kong P, Xie X, Li F, Liu Y, Lu Y. Placenta mesenchymal stem cell accelerates wound healing by enhancing angiogenesis in diabetic Goto-Kakizaki (GK) rats. Biochem Biophys Res Commun. 2013;438:410-9.

42. Chotinantakul K, Dechsukhum C, Dejjuy D, Leeanansaksiri W. Enhancement of wound closure in diabetic mice by ex vivo expanded cord blood CD34+ cells. Cell Mol Biol Lett. 2013;18:263-83.

43. Tark KC, Hong JW, Kim YS, Hahn SB, Lee WJ, Lew DH. Effects of human cord blood mesenchymal stem cells on cutaneous wound healing in leprdb mice. Ann Plast Surg. 2010;65:565-72.

44. Nie C, Yang D, Xu J, Si Z, Jin X, Zhang J. Locally administered adiposederived stem cells accelerate wound healing through differentiation and vasculogenesis. Cell Transplant. 2011;20:205-16.

45. Maharlooei MK, Bagheri M, Solhjou Z, Jahromi BM, Akrami M, Rohani L, Monabati A, Noorafshan A, Omrani GR. Adipose tissue derived mesenchymal stem cell (AD-MSC) promotes skin wound healing in diabetic rats. Diabetes Res Clin Pract. 2011;93:228-34.

46. Di Rocco G, Gentile A, Antonini A, Ceradini F, Wu JC, Capogrossi MC, Toietta G. Enhanced healing of diabetic wounds by topical administration of adipose tissue-derived stromal cells overexpressing stromal-derived factor-1: biodistribution and engraftment analysis by bioluminescent imaging. Stem Cells Int. 2010;2011:304562.

47. Stepanovic V, Awad O, Jiao C, Dunnwald M, Schatteman GC. Leprdb diabetic mouse bone marrow cells inhibit skin wound vascularization but promote wound healing. Circ Res. 2003;92:1247-53.

48. Kim JY, Song SH, Kim KL, Ko JJ, Im JE, Yie SW, Ahn YK, Kim DK, Suh W. Human cord blood-derived endothelial progenitor cells and their conditioned media exhibit therapeutic equivalence for diabetic wound healing. Cell Transplant. 2010;19:1635-44.

49. Lin CD, Allori AC, Macklin JE, Sailon AM, Tanaka R, Levine JP, Saadeh PB, Warren SM. Topical lineage-negative progenitor-cell therapy for diabetic wounds. Plast Reconstr Surg. 2008;122:1341-51.

50. Ha X, Yin Q, Dong F, Jia Q, Lv T. Study on bone marrow mesenchymal stem cells transfected with adenovirus hepatocyte growth factor gene promoting wounds repair in diabetic rats. Zhongguo Xiu Fu Chong Jian Wai Ke Za Zhi. 2010;24:1520-4.

51. Tian H, Lu Y, Shah SP, Hong S. 14S,21R-dihydroxydocosahexaenoic acid remedies impaired healing and mesenchymal stem cell functions in diabetic wounds. J Biol Chem. 2011;286:44434453.

52. Nambu M, Kishimoto S, Nakamura S, Mizuno H, Yanagibayashi S, Yamamoto N Azuma R, Nakamura S, Kiyosawa T, Ishihara M, Kanatani Y. Accelerated wound healing in healing-impaired $\mathrm{db} / \mathrm{db}$ mice by autologous adipose tissue-derived stromal cells combined with atelocollagen matrix. Ann Plast Surg. 2009;62:317-21.

53. Lee KB, Choi J, Cho SB, Chung JY, Moon ES, Kim NS, Han HJ. Topical embryonic stem cells enhance wound healing in diabetic rats. J Orthop Res. 2011;29:1554-62

54. Pedroso DC, Tellechea A, Moura L, Fidalgo-Carvalho I, Duarte J, Carvalho E, Ferreira L. Improved survival, vascular differentiation and wound healing potential of stem cells co-cultured with endothelial cells. PLoS One. 2011;6:e16114.

55. Inoue H, Murakami T, Ajiki T, Hara M, Hoshino Y, Kobayashi E. Bioimaging assessment and effect of skin wound healing using bone-marrow-derived mesenchymal stromal cells with the artificial dermis in diabetic rats. J Biomed Opt. 2008;13:064036.

56. Amos PJ, Kapur SK, Stapor PC, Shang H, Bekiranov S, Khurgel M, Rodeheaver GT, Peirce SM, Katz AJ. Human adipose-derived stromal cells accelerate diabetic wound healing: impact of cell formulation and delivery. Tissue Eng Part A. 2010;16:1595-606.

57. Kwon DS, Gao X, Liu YB, Dulchavsky DS, Danyluk AL, Bansal M, Chopp M, McIntosh K, Arbab AS, Dulchavsky SA, Gautam SC. Treatment with bone marrow-derived stromal cells accelerates wound healing in diabetic rats. Int Wound J. 2008:5:453-63.

58. Badillo AT, Redden RA, Zhang L, Doolin EJ, Liechty KW. Treatment of diabetic wounds with fetal murine mesenchymal stromal cells enhances wound closure. Cell Tissue Res. 2007;329:301311.

59. Shrestha $C$. Enhanced healing of diabetic wounds by subcutaneous administration of human umbilical cord derived stem cells and their conditioned media. Int J Endocrinol. 2013;2013:10.

60. Kim SW, Zhang HZ, Guo L, Kim JM, Kim MH. Amniotic mesenchymal stem cells enhance wound healing in diabetic NOD/SCID mice through high angiogenic and engraftment capabilities. PLoS One. 2012;7:e41105.

61. Meng H, Wang Z, Wang W, Li W, Wu Q, Lei X, Ouyang X, Liang Z. Effect of osteopontin in regulating bone marrow mesenchymal stem cell treatment of skin wounds in diabetic mice. Diabetes Metab Res Rev. 2014;30:457-66.

62. Argolo Neto NM, Del Carlo RJ, Monteiro BS, Nardi NB, Chagastelles PC, de Brito AF, Reis AM. Role of autologous mesenchymal stem cells associated with platelet-rich plasma on healing of cutaneous wounds in diabetic mice. Clin Exp Dermatol. 2012;37:544-53.

63. Navone SE, Pascucci L, Dossena M, Ferri A, Invernici G, Acerbi F, Cristini S, Bedini G, Tosetti V, Ceserani V, Bonomi A, Pessina A, Freddi G, Alessandrino A Ceccarelli P, Campanella R, Marfia G, Alessandri G, Parati EA. Decellularized silk fibroin scaffold primed with adipose mesenchymal stromal cells improves wound healing in diabetic mice. Stem Cell Res Ther. 2014;5:7.

64. Tong C, Hao H, Xia L, Liu J, Ti D, Dong L, Hou Q, Song H, Liu H, Zhao Y, Fu X, Han W. Hypoxia pretreatment of bone marrow-derived mesenchymal stem cells seeded in a collagenchitosan sponge scaffold promotes skin wound healing in diabetic rats with hindlimb ischemia. Wound Repair Regen. 2016;24:45-56.

65. Marrotte EJ, Chen DD, Hakim JS, Chen AF. Manganese superoxide dismutase expression in endothelial progenitor cells accelerates wound healing in diabetic mice. J Clin Invest. 2010;120:4207-19.

66. Sivan-Loukianova E, Awad OA, Stepanovic V, Bickenbach J, Schatteman GC. CD34+ blood cells accelerate vascularization and healing of diabetic mouse skin wounds. J Vasc Res. 2003:40:368-77.

67. Nambu M, Ishihara M, Kishimoto S, Yanagibayashi S, Yamamoto N, Azuma R, Kanatani Y, Kiyosawa T, Mizuno H. Stimulatory effect of autologous adipose tissue-derived stromal cells in an Atelocollagen matrix on wound healing in diabetic db/db mice. J Tissue Eng. 2011:2011:158105.

68. Shin L, Peterson DA. Impaired therapeutic capacity of autologous stem cells in a model of type 2 diabetes. Stem Cells Transl Med. 2012;1:125-35.

69. Maksimova N, Krasheninnikov M, Zhang Y, Ponomarev E, Pomytkin I, Melnichenko G, Lyundup A. Early passage autologous mesenchymal stromal cells accelerate diabetic wound reepithelialization: a clinical case study. Cytotherapy. 2017;19(12):1548-50.

70. Tian HM, Yu KH, Lin FP, Du XJ, Zen XN, Yu XJ. PTA combined with transplantation of autologous bone marrow stem cells for diabetic foot: Observation of clinical effect. 2016;25:1040-1043. https://doi.org/10.3969/j. issn.1008794X.2016.12.004.

71. Qin HL, Zhu XH, Zhang B, Zhou L, Wang WY. Clinical evaluation of human umbilical cord mesenchymal stem cell transplantation after angioplasty for diabetic foot. Exp Clin Endocrinol Diabetes. 2016;124:497-503.

72. Xu S-M, Liang T. Clinical observation of the application of autologous peripheral blood stem cell transplantation for the treatment of diabetic foot gangrene. Exp Ther Med. 2016;11:283-8.

73. Kirana S, Stratmann B, Prante C, Prohaska W, Koerperich H, Lammers D, Gastens MH, Quast T, Negrean M, Stirban OA, Nandrean SG, Gotting C, Minartz P, Kleesiek K, Tschoepe D. Autologous stem cell therapy in the treatment of limb ischaemia induced chronic tissue ulcers of diabetic foot patients. Int J Clin Pract. 2012;66:384-93.

74. Maslowski L, Paprocka M, Dus D, Grendziak R, Kubiak J, Cyzewska-Buczynska A. Wojtowicz-Prus E, Czarnecka A, Witkiewicz. Autotransplantation of the adipose tissue derived stem cells for diabetic foot ulcers healing. In: 
Jahrestagung der Deutschen Gesellschaft für Angiologie. Freiburg: VASA; 2015;44(Suppl 88): 71-72.

75. Dubsky M, Jirkovska A, Bem R, Fejfarova V, Pagacova L, Nemcova A, Sixta B, Chlupac J, Peregrin JH, Sykova E, Jude EB. Comparison of the effect of stem cell therapy and percutaneous transluminal angioplasty on diabetic foot disease in patients with critical limb ischemia. Cytotherapy. 2014;16:1733-8.

76. Dubsky M, Jirkovska A, Bem R, Fejfarova V, Pagacova L, Sixta B, Varga M, Langkramer S, Sykova E, Jude EB. Both autologous bone marrow mononuclear cell and peripheral blood progenitor cell therapies similarly improve ischaemia in patients with diabetic foot in comparison with control treatment. Diabetes Metab Res Rev. 2013;29:369-76.

77. Wang GY, Zhu LY, Ma LC, Hu LY, Li XL, Yang SL, Shan W, Hou RR. Stem cell transplantation for the treatment of diabetic foot. Chinese J Tissue Eng Res. 2013:17:173-80.

78. Dubsky M, Jirkovska A, Bem R, Pagacova L, Fejfarova V, Varga M, Skibova J, Langkramer S, Sykova E. Treatment of critical limb ischemia and diabetic foot disease by the use of autologous stem cells. Vnitrni lekarstvi. 2011;57:451-5.

79. Lu D, Chen B, Liang Z, Deng W, Jiang Y, Li S, Xu J, Wu Q, Zhang Z, Xie B, Chen $S$. Comparison of bone marrow mesenchymal stem cells with bone marrow-derived mononuclear cells for treatment of diabetic critical limb ischemia and foot ulcer: a double-blind, randomized, controlled trial. Diabetes Res Clin Pract. 2011;92:26-36.

80. Prochazka V, Gumulec J, Chmelova J, Klement P, Klement GL, Jonszta T, Czerny D, Krajca J. Autologous bone marrow stem cell transplantation in patients with end-stage chronical critical limb ischemia and diabetic foot. Vnitrni lekarstvi. 2009:55:173-8.

81. Chen B, Lu DB, Liang ZW, Jiang YZ, Wang FH, Wu QN, Zhang ZH. Autologous bone marrow mesenchymal stem cell transplantation for treatment of diabetic foot following amplification in vitro. J Clin Rehabil Tissue Eng Res. 2009;13:6227-30.

82. Yu C. Umbilical cord blood stem cell transplantation for the treatment of diabetic foot in 11 cases. J Clin Rehabil Tissue Eng Res. 2009;13(23):4593-96.

83. Zhao J. Transplantation of autologous bone marrow stem cells for the treatment of severe lower limb arterial occlusion in 15 cases. J Clin Rehabil Tissue Eng Res. 2009;13:7959-63.

84. Mao H, Zhao S, Wang HX, Deng L. Autologous peripheral blood stem cells transplantation for the treatment of diabetic vascular disorder in lower extremities and diabetic feet: Self-control observation of 89 patients. 2008: 12:4197-200.

85. Vojtassak J, Danisovic L, Kubes M, Bakos D, Jarabek L, Ulicna M, Blasko M. Autologous biograft and mesenchymal stem cells in treatment of the diabetic foot. Neuro Endocrinol lett. 2006;27(Suppl 2):134-7.

86. Zhang HJ, Gu YQ, Guo LR, Kai F. Autologous transplantation of bone marrow stem cells for severe diabetic feet: a report of 11 cases. 2006;10:116-118.

87. Kawamura A, Horie T, Tsuda I, Ikeda A, Egawa H, Imamura E, lida J, Sakata H, Tamaki T, Kukita K, Meguro J, Yonekawa M, Kasai M. Prevention of limb amputation in patients with limbs ulcers by autologous peripheral blood mononuclear cell implantation. Ther Apher Dialysis. 2005;9:59-63.

88. Zhou X. Study on autologous peripheral blood stem cell collected by MCS +ED therapy for diabetic foot. J Clin Transfus Lab Med. 2010;1:21-24.

89. Wang S, Sun S, Wang X, Wu H, Zhao R, Wen M. The Clinical Analysis of 22 Cases with Diabetic Foot Receiving Autologous Bone Marrow Stem Cell Transplantation (ABMSCTP) Therapy. J Dali University 2010;8:45-47.

90. Huang Y-c. Curative effect of percutaneous transluminal Angioplas combined with transplantation of autologous Pedpheral blood stem cell for diabetic foot. Chinese J Gen Prac. 2010:8:947-48.

91. Debin L, Youzhao J, Ziwen L, Xiaoyan L, Zhonghui Z, Bing C. Autologous transplantation of bone marrow mesenchymal stem cells on diabetic patients with lower limb ischemia. J Med Coll PLA. 2008:23:106-15.

92. Humpert PM, Bartsch U, Konrade I, Hammes HP, Morcos M, Kasper M, Bierhaus A, Nawroth PP. Locally applied mononuclear bone marrow cells restore angiogenesis and promote wound healing in a type 2 diabetic patient. Exp Clin Endocrinol Diabetes. 2005;113:538-40.

93. Bartsch T, Brehm M, Falke T, Kogler G, Wernet P, Strauer BE. Rapid healing of a therapy refractory diabetic foot after transplantation of autologous bone marrow stem cells. Med Klin (Munich). 2005;100:676-80.

94. Kohlman-Trigoboff D, Lawson JH, Murphy MP. Stem cell use in a patient with an ischemic foot ulcer: a case study. J Vasc Nurs. 2006;24:56-61.

95. Kirana S, Stratmann B, Lammers D, Negrean M, Stirban A, Minartz P, Koerperich H, Gastens MH, Gotting C, Prohaska W, Kleesiek K, Tschoepe D.
Wound therapy with autologous bone marrow stem cells in diabetic patients with ischaemia-induced tissue ulcers affecting the lower limbs. Int J Clin Pract. 2007;61:690-2.

96. Lee HC, An SG, Lee HW, Park JS, Cha KS, Hong TJ, Park JH, Lee SY, Kim SP, Kim YD, Chung SW, Bae YC, Shin YB, Kim JI, Jung JS. Safety and effect of adipose tissue-derived stem cell implantation in patients with critical limb ischemia: a pilot study. Circ J. 2012;76:1750-60.

97. Dash NR, Dash SN, Routray P, Mohapatra S, Mohapatra PC. Targeting nonhealing ulcers of lower extremity in human through autologous bone marrow-derived mesenchymal stem cells. Rejuvenation Res. 2009;12:359-66.

98. Jain P, Perakath B, Jesudason MR, Nayak S. The effect of autologous bone marrow-derived cells on healing chronic lower extremity wounds: results of a randomized controlled study. Ostomy Wound Manage. 2011;57:38-44.

99. Kawamura A, Horie T, Tsuda I, Abe Y, Yamada M, Egawa H, lida J, Sakata H, Onodera K, Tamaki T, Furui H, Kukita K, Meguro J, Yonekawa M, Tanaka S. Clinical study of therapeutic angiogenesis by autologous peripheral blood stem cell (PBSC) transplantation in 92 patients with critically ischemic limbs. J Artif Organs. 2006;9:226-33.

100. Yang XF, Wu YX, Wang HM, Xu YF, Lu X, Zhang YB, Wang F, Zhang Y. Autologous peripheral blood stem cells transplantation in treatment of 62 cases of lower extremity ischemic disorder. Zhonghua Nei Ke Za Zhi. 2005;:44:95-8.

101. Qin HL, He KW, Bin G, Ji YL, Huang YC, Wang SQ, Hu GP, Zhou XY. Human umbilical cord mesenchymal stem cell transplantation combined with angioplasty for diabetic foot: 3 months angiographic evaluation. Chinese J Tissue Eng Res. 2013;17:2544-51.

102. Bura A, Planat-Benard V, Bourin P, Silvestre JS, Gross F, Grolleau JL, Saint-Lebese B, Peyrafitte JA, Fleury S, Gadelorge M, Taurand M, Dupuis-Coronas S, Leobon B, Casteilla L. Phase I trial: the use of autologous cultured adipose-derived stroma/stem cells to treat patients with nonrevascularizable critical limb ischemia. Cytotherapy. 2014;16:245-57.

103. Yoshikawa T, Mitsuno H, Nonaka I, Sen Y, Kawanishi K, Inada Y, Takakura Y, Okuchi K, Nonomura A. Wound therapy by marrow mesenchymal cell transplantation. Plast Reconstr Surg. 2008;121:860-77.

104. Gerami-Naini B, Smith A, Maione AG, Kashpur O, Carpinito G, Veves A, Mooney DJ, Garlick JA. Generation of induced pluripotent stem cells from diabetic foot ulcer fibroblasts using a nonintegrative Sendai virus. Cell Reprogram. 2016;18:214-23.

105. Okawa T, Kamiya H, Himeno T, Kato J, Seino Y, Fujiya A, Kondo M, Tsunekawa S, Naruse K, Hamada Y, Ozaki N, Cheng Z, Kito T, Suzuki H, Ito S, Oiso Y, Nakamura J, Isobe K. Transplantation of neural crest-like cells derived from induced pluripotent stem cells improves diabetic polyneuropathy in mice. Cell Transplant. 2013;22:1767-83.

106. Finnerty CC, Przkora R, Herndon DN, Jeschke MG. Cytokine expression profile over time in burned mice. Cytokine. 2009;45:20-5.

107. Shen G-Y, Park I-H, Song Y-S, Joo H-W, Lee Y, Shin J-H, Kim K-S, Kim H. Local injection of granulocyte-colony stimulating factor accelerates wound healing in a rat excisional wound model. Tissue Eng Regen Med. 2016;13:297-303.

108. Cruciani M, Lipsky BA, Mengoli C, de Lalla F. Granulocyte-colony stimulating factors as adjunctive therapy for diabetic foot infections. Cochrane Database Syst Rev. 2013;8:Cd006810.

109. Zonta S, De Martino M, Bedino G, Piotti G, Rampino T, Gregorini M, Frassoni F, Dal Canton A, Dionigi P, Alessiani M. Which is the most suitable and effective route of administration for mesenchymal stem cell-based immunomodulation therapy in experimental kidney transplantation: endovenous or arterial? Transplant Proc. 2010:42:1336-40.

110. Ho JH, Tseng TC, Ma WH, Ong WK, Chen YF, Chen MH, Lin MW, Hong CY, Lee OK. Multiple intravenous transplantations of mesenchymal stem cells effectively restore long-term blood glucose homeostasis by hepatic engraftment and beta-cell differentiation in streptozocin-induced diabetic mice. Cell Transplant. 2012;21:997-1009.

111. Acosta L, Hmadcha A, Escacena N, Perez-Camacho I, de la Cuesta A, Ruiz-Salmeron R, Gauthier BR, Soria B. Adipose mesenchymal stromal cells isolated from type 2 diabetic patients display reduced fibrinolytic activity. Diabetes. 2013:62:4266-9.

112. Darinskas A, Paskevicius M, Apanavicius G, Vilkevicius G, Labanauskas L, Ichim TE, Rimdeika R. Stromal vascular fraction cells for the treatment of critical limb ischemia: a pilot study. J Transl Med. 2017;15:143.

113. Kirby GTS, Mills SJ, Cowin AJ, Smith LE. Stem cells for cutaneous wound healing. Biomed Res Int. 2015;2015:285869. 
114. Choudhery MS, Badowski M, Muise A, Pierce J, Harris DT. Donor age negatively impacts adipose tissue-derived mesenchymal stem cell expansion and differentiation. J Transl Med. 2014;12(8):e1-e14.

115. Beane OS, Fonseca VC, Cooper LL, Koren G, Darling EM. Impact of aging on the regenerative properties of bone marrow-, muscle-, and adipose-derived mesenchymal stem/stromal cells. PLoS One. 2014;9:e115963.

116. Duscher D, Rennert RC, Januszyk M, Anghel E, Maan ZN, Whittam AJ, Perez MG, Kosaraju R, Hu MS, Walmsley GG, Atashroo D, Khong S, Butte AJ, Gurtner GC. Aging disrupts cell subpopulation dynamics and diminishes the function of mesenchymal stem cells. Sci Rep. 2014;4:7144.

117. Yan J, Tie G, Wang S, Messina KE, DiDato S, Guo S, Messina LM. Type 2 diabetes restricts multipotency of mesenchymal stem cells and impairs their capacity to augment postischemic neovascularization in $\mathrm{db} / \mathrm{db}$ mice. J Am Heart Assoc. 2012;1:e002238.

118. Mansilla E, Aquino VD, Roque G, Tau JM, Maceira A. Time and regeneration in burns treatment: heading into the first worldwide clinical trial with cadaveric mesenchymal stem cells. Burns. 2012:38:450-2.

119. Gattazzo F, Urciuolo A, Bonaldo P. Extracellular matrix: a dynamic microenvironment for stem cell niche. Biochim Biophys Acta. 2014;1840:2506-19.

120. Chen JS, Wong VW, Gurtner GC. Therapeutic potential of bone marrowderived mesenchymal stem cells for cutaneous wound healing. Front Immunol. 2012;3:192

121. Critser PJ, Kreger ST, Voytik-Harbin SL, Yoder MC. Collagen matrix physical properties modulate endothelial colony forming cell-derived vessels in vivo. Microvasc Res. 2010;80:23-30.

122. Gower RM, Shea LD. Biomaterial scaffolds for controlled, localized gene delivery of regenerative factors. Adv Wound Care. 2013;2:100-6.

123. Mudera V, Morgan M, Cheema U, Nazhat S, Brown R. Ultra-rapid engineered collagen constructs tested in an in vivo nursery site. J Tissue Eng Regen Med. 2007;1:192-8

124. Mulder G, Tenenhaus M, D'Souza GF. Reduction of diabetic foot ulcer healing times through use of advanced treatment modalities. Int J Low Extrem Wounds. 2014;13:335-46.

\section{Ready to submit your research? Choose BMC and benefit from:}

- fast, convenient online submission

- thorough peer review by experienced researchers in your field

- rapid publication on acceptance

- support for research data, including large and complex data types

- gold Open Access which fosters wider collaboration and increased citations

- maximum visibility for your research: over $100 \mathrm{M}$ website views per year 